\title{
UTILIZATION OF ALBERTA GAS
}

\begin{abstract}
ROBERT C. MUIR*
This paper surveys recent Alberta legislation, regulations and policies with respect to the natural gas industry. The paper discusses proposed changes to the Jumping Pound Formula as a method of determining gas process charges, the amendment to the Oil and Gas Conservation Act requiring a permit to utilize gas in Alberta and the enactment of the Rural Gas Act and the Natural Gas Rebates Act. With respect to the removal of gas from the Province, the paper reviews the policies of the Government of Alberta to increase the field price of natural gas.
\end{abstract}

\section{INTRODUCTION}

The past year has seen an abundance of legislation and regulations in both the Federal and Provincial jurisdictions. Leaving aside constitutional issues, taxes and budgetary matters, there still remain some items of interest involving gas.

\section{GAS UTILITIES ACT}

\section{Gas Processing Charges - Jumping Pound Formula ${ }^{2}$}

Much of the natural gas produced in Alberta is sour and requires processing to render it marketable. The lessee usually obtains the right to deduct from the plant outlet price expenses incurred in gathering and processing the gas so as to arrive at a price or value back at the wellhead on which royalty to the lessor is calculated. The method used in determining these deductions is the Jumping Pound Formula, first adopted by the Public Utilities Board in a dispute between Shell Oil and Rabson Oil over processing charge deductions in the Jumping Pound field. With regard to freehold royalty, the Public Utilities Board has jurisdiction under s. 9 of the Gas Utilities Act to determine deductions and the formula for ascertaining the same, subject to certain questions involving the Board's rights and duties in interpreting contracts.

Under the Jumping Pound calculation, the plant and gathering operation is regarded as a notional corporation which has invested certain monies. The formula provides for a rate base founded on capital investment in the plant and gathering system, less cumulative depreciation, plus working capital.

An annual rate of return is allowed at a percentage which, when multiplied by the rate base, provides a return to the notional corporation on its investment. The Board assumes that the capitalization of the plant and gathering system consists of $50 \%$ debt and $50 \%$ equity. In the Pincher Creek case ${ }^{3}$ the Board allowed a corporate rate of return on capitalization of $8.25 \%$ based on $50 \%$ debt at $5.09 \%$,

- Barrister and Solicitor, firm of Ballem, McDill and MacInnes, Calgary, Alberta.

1 R.S.A. 1970 , c. 158 as amended.

2 For an excellent analysis of the deduction of expenses by lessees see Rae, Royalty Clauses in Oil \& Gas Leases, (1965-66) 4 Alta. L. Rev. 323 at 338.

${ }^{3}$ Calgary \& Edmonton Corporation Ltd. v. British American Oil Co. Ltd. (1963) 40 O.L.R. 972 (Alta. A.D.); See Supra n. 2, at 346. 
$10 \%$ preferred equity at $7 \%$ and $40 \%$ common equity at $12.5 \%$. In addition to the rate of return the lessee is entitled to deduct operating and amortization expenses. A deduction for income tax is also allowed, based on a notional income tax payable on assumed net income from the plant and gathering system. Thus a total annual expense is arrived at consisting of return on investment, operating costs, depreciation and income tax which, when divided by the number of Mcf produced at the plant outlet, gives a deduction in cents per Mcf.

The Alberta Crown has never considered itself bound by the Jumping Pound Formula. Crown lessees submit their calculations each year based on the Jumping Pound Formula with certain items deleted from the rate base and working capital requirements. After a period of time the Crown will reply that the charge will be X cents per Mcf, usually lower than the submitted charge. No revised calculation is tendered by the Crown and how the actual charge is arrived at is always somewhat of a mystery.

Some time ago a cryptic announcement emanated from Edmonton to the effect that the Jumping Pound Formula would be replaced by a "cost allowance scheme". When this new scheme was first proposed, there were predictions of maximum charges, similar treatment of all plants (irrespective of past history, cost and design), and other similar "disasters". It is to be hoped that reason will prevail, that the essence of the Jumping Pound Formula will be retained, that some kind of manual will be published stating in detail what items can and cannot be included in formula calculations, and that rates of return which reflect the real economic situation will be obtainable.

\section{Section 27 - Gas Utilities Act}

An application was made recently to the Public Utilities Board pursuant to s. 27 of the Gas Utilities Act asking that the Board order a gas processing plant which is processing gas in one pool to process gas forwarded from another pool. Section $2(f)$ of the Act says that a gas utility includes a "scrubbing plant" and s. 2(j) defines a "scrubbing plant" as any plant for the treating of gas for the removal therefrom of $\mathrm{H}_{2} \mathrm{~S}$ or other deleterious substance. Section 27 (d) provides that the Board, without any prior approval, without holding a hearing, and on its own initiative may require an owner of a scrubbing plant to establish and operate any reasonable extension of his existing facilities. In my opinion neither s. 27(d) nor any other portion of the Act confers common processor jurisdiction on the Public Utilities Board. Sections 54-56 of the Oil and Gas Conservation Act $t^{4}$ are relevant in this context. That Act sets out what the legislature intended with regard to forced processing, namely, that the Energy Resources Conservation Board (ERCB), with the approval of the Lieutenant-Governor in Council, after a hearing and upon application, may declare the owner or operator of a processing plant processing gas produced from a pool or pools to be a common processor of gas from the pool or pools. Where the ERCB has made such a declaration and the common processor and the person desiring to have his gas processed cannot agree as to the costs, charges, or deductions for processing, then either party may apply to the Public Utilities Board under the Gas Utilities Act.

\section{Section 6 - Gas Utilities Act}

This section will probably be put to extensive use in the next few years. It provides that, notwithstanding any contract, the Public Utilities Board may fix and determine the just and reasonable prices to be paid for any gas used, consumed, stored, or retained within Alberta. The Alberta Government's policy

4 R.S.A. 1970, c. 267 as amended. 
assumes that, in the past, Albertans have been denied a just return for their natural gas. One of the means by which the Government intends to ensure that a just return is received is by requiring more upgrading of gas within Alberta. ${ }^{5}$ This will result in more sales of gas for use within the province and, as vendors and purchasers come to the conclusion that the contracts which they have entered into are unfair, they will look to the Public Utilities Board to supply a remedy pursuant to s. 6. The rebate system will shelter local industrial and residential consumers from the increasing price of natural gas. The traditional aim of Alberta producers has been to avoid sales in the local market. If the Public Utilities Board decides that producers are entitled to commodity value for gas, irrespective of whether the contract is for gas moving into the local market or the outside market, then the disinclination of producers to sell locally will evaporate.

\section{GAS USE IN ALBERTA}

We note firstly the Oil and Gas Conservation Act Amendment Act 1974 which was introduced by the Minister of Industry and Commerce and was assented to on June 6,1974 . This Act provides that no gas or gas product will be used in Alberta as a raw material or fuel in the production of ammonia, urea, ethanol, methanol, carbon black or any petrochemical product unless the ERCB, subject to the authorization of the Lieutenant-Governor in Council, grants an industrial development permit. "Gas product" means any constituent of gas extracted by processing, including methane, ethane, propane, etc., but not including sulphur or sulphur components.

The Board is not to grant the permit unless it is in the public interest to do so, having regard to, among other unspecified considerations:

(a) the efficient use, without waste, of gas or gas products; and

(b) the present and future availability of hydrocarbons in Alberta.

The Board is not required to hold a hearing upon application for a permit.

Certain exemptions from the operation of the Act are granted on basis related to existing volumes being used in existing facilities or on basis set out in regulations.

In April, 1973, the Minister of Telephones and Utilities issued Position Paper Number 11 dealing with a "Rural Gas Policy" for Albertans. The main recommendation was that natural gas be brought to the bulk of those rural consumers (20\% of Albertans) who are not served by natural gas. The Government concluded that cross-subsidization through rates is no longer possible across the province and that equalization has to be achieved through the general provincial revenues - either by way of grant or guaranteed loan, or both. Subsequently, the Rural Gas Act ${ }^{B}$ became effective November 29th, 1973. The Minister in charge is the Minister of Telephones and Utilities. From a producer point of view a very significant concept is that of "Gas Alberta". The Act specifies that Gas Alberta is a section of the Rural Utilities Branch of the Department of Telephones and Utilities. Notwithstanding anything in the Act or in any permit issued under the Gas Resources Preservation Act ${ }^{7}$, the owner of gas shall supply gas at a reasonable price to Gas Alberta if, in the opinion of the Energy Resources

5 Alta. Govt. Position Paper No. 18, "Natural Gas Rebate Plan for Albertans", May, 1974.

S.A. 1973 , c. 83 .

R.S.A. 1970 , c. 157 as amended. 
Conservation Board, the gas can be reasonably supplied by the owner. Gas Alberta has the power to buy, sell and exchange gas or act as a broker in sales and purchases of gas.

It is axiomatic in the gas business that a producer will seek to maximize the price to be received for its gas; it will also seek to ensure that the volumes of gas to be sold will bear some logical relationship to the producibility of the wells. Otherwise part of the producibility will be committed to one market and the remainder, and sometimes larger portion, will not be of sufficient volume to justify pipeline construction to serve another market. If a local utility is able to arrange for a producer to become committed to Gas Alberta on some interruptible or low daily volume basis the producer may be unable to market the remainder of its producibility to some other customer. Thus it is to be hoped that the great powers vested in the Minister under the Rural Gas Act will be exercised with some discretion and with regard to the orderly marketing of gas in the province.

Alberta Government Position Paper No. 18 entitled "Natural Gas Rebate Plan for Albertans" was issued in May, 1974. The paper states in part that the Government will rebate, for the benefit of Alberta consumers, a substantial portion of incremental revenues from higher gas royalty schedules, with the objective of enabling Albertans to continue to enjoy the lowest price for natural gas in Canada.

The plan is to apply only to those individuals and establishments consuming up to one billion cubic feet per year. An industry consuming in excess of that level may make application to the Minister for a special rebate. The Public Utilities Board will check to ensure that gas purchase contracts and charges made for natural gas to consumers are just and reasonable. This is to ensure that the benefit of natural gas rebates passes through to the consumers for whom it is intended and that unreasonable prices above fair market value are not charged by producers to Alberta vendors for Alberta consumers. Rebates will not generally be paid in respect to utility-owned reserves, for which the consumer already pays indirectly by means of the allowable rate-of-return on the investment of regulated utilities. These utility-owned gas reserves are not subject to the "opportunity price" open to other producers.

Subsequent to the issuance of Position Paper No. 18, the Natural Gas Rebates Act (Bill 54) was passed by the legislature to implement the policies as set out in the position paper. No rebate is to be made in respect of gas delivered prior to January 1, 1974. A rebate is made only on gas to be consumed or used in Alberta and must be passed on to "eligible consumers". Regulations are forthcoming which will, presumably, provide details as to how the rebates are to be applied for and calculated, confer jurisdiction on the Public Utilities Board in the area of rebates, and prescribe the rights and duties of persons applying for or receiving rebates.

\section{ALBERTA GAS TRUNK LINE COMPANY ACT}

A.t the present time the Plains system of Alberta Gas Trunk generally transports gas for TransCanada Pipe Lines Limited for removal east and the Foothills system moves Alberta and Southern Gas Co. Ltd. gas to California. Gas in the AGTL lines is not owned by AGTL but is owned by the purchasers, Alberta and Southern, WestCoast, Consolidated, TransCanada, and others who enter into transmission agreements with AGTL setting out transmission costs

8 S.A. 1954, c. 37 as amended. 
from field gate to the Alberta border. If the Pan-Alberta project is approved by the National Energy Board there will be a great deal of new construction done by AGTL including more cross-overs from the Foothills to the Plains system and vice-versa.

In 1973 the Alberta Gas Trunk Line Company Act ${ }^{9}$ was amended to give AGTL power to exchange gas in addition to the power it already had to commingle gas. "Commingling" means the mixing together or blending of gases received by AGTL from various points on its system for transmission. "Exchange" means the exchange of gas received by AGTL for delivery to a point in the AGTL system to which physical transmission of such gas is not practical, for other gas in the AGTL system which can practically be delivered to that point.

Pursuant to s. 30 (b) of the Alberta Gas Trunk Line Company Act, AGTL has the power on an exchange or commingling to make such compensating adjustments for volume, heating value and component content as in its opinion are warranted. Pursuant to a 1974 amendment to the Act (assented to June 6, 1974) the ERCB has jurisdiction, after implementation of an exchange or pursuant to a commingling, to determine the reasonableness of any decision made by AGTL upon notice to and hearing of the parties interested. Adjustments may involve not only BTU adjustment but ethane content and other component adjustments in circumstances where up-grading plants have bought gas in the field having a certain content desirable for the operation of the particular plants.

\section{REMOVAL OF GAS FROM ALBERTA}

As to removal of gas from Alberta, the governing statute is the Gas Resources Preservation Act. ${ }^{10}$ In December, 1973 an amendment ${ }^{11}$ was introduced in the Alberta legislature restricting the application of the Act "only to gas or propane derived from petroleum or natural gas recovered pursuant to a lease, license, permit or reservation issued under the Mines and Minerals Act or its predecessors or the regulations thereunder". The amendment was passed subject to proclamation and has not been proclaimed. Accordingly, the unamended Gas Resources Preservation Act applies to all removal of gas from Alberta. Presumably, if the Act is attacked on constitutional grounds, the attack can be repulsed by proclaiming the amendment so as to restrict the application of the Act to gas owned by the Crown in right of Alberta, thus asserting a provincial right to regulate removal of gas in which the province has a proprietary right.

Under the existing unamended Gas Resources Preservation Act, a person proposing to remove gas from Alberta may make an application to the Energy Resources Conservation Board for a permit authorizing such removal. The Board is prohibited from granting a removal permit unless it is, in the Board's opinion, in the public interest to do so having regard to:

(a) the present and future needs of persons within Alberta, and

(b) the established reserves and trends in growth and discovery of reserves of gas in Alberta.

If the Board finds that it is in the public interest to grant a permit it may do so with the approval of the Lieutenant-Governor in Council. Such matters as the economic feasibility of the project, the terms, including field price of the

\footnotetext{
S.A. 1973 , c. 4.

10 Supra, n. 7.

11 S.A. 1973, c. 90.
} 
gas purchase contract and the removal price, are not strictly matters for inquiry by the Board. However, in addition to appraising applications under the Act the Board will also offer its views on these matters in relation to the Alberta Government policy statement entitled "Alberta Government Statement of New Natural Gas Policies for Albertans", dated November 16, 1972.

An interesting point with respect to gas reserves is the theory that reserves increase as gas prices increase. Before both the ERCB and the NEB, evidence has been led to the effect that higher gas prices in the range of $60 \phi / \mathrm{Mcf}$ would make economic the drilling of additional wells and the installation of the compression needed to accomplish increased recovery. Historically the ERCB correlation between abandonment pressure and the depth of reservoirs reflected a gas price of approximately $15 \% /$ Mcf. The ERCB has now held ${ }^{12}$ that abandonment should be considered to occur when revenue matches operating costs and it has adjusted its recovery factors for all pools in the province and increased its estimate of Alberta marketable reserves. However, because this increase is dependant upon the economic health of the industry, the assumption that it exists is always open to attack in times of economic sickness.

Turning now to those matters which the Board need not consider but on which it will give its advice to the Lieutenant-Governor in Council so that he can decide whether to approve the Board removal permit, the first question is whether the purchase contract terms and conditions meet the Government pricing policy which I have referred to above. The Government view on pricing is: ${ }^{13}$

(a) that the mid-1972 average field price of gas of $16 \phi$ per Mcf was 10 to 20 cents per Mcf less than the field value; and

(b) that gas purchase contracts shall provide for price renegotiation every second year.

Gas bought in the field twenty months ago at $40 \%$ per Mcf would have more than met the price range endorsed by the Alberta Government. However, during the period of administrative delay between application and decision, sizeable increases in prices of crude oils and fuel oils will have, in the opinion of the ERCB, substantially increased the field value of Alberta gas. The Board will hold that the purchase contract prices do not meet current and anticipated field values.

If two-year renegotiations are not in the contract the Cabinet is unlikely to approve the Board removal order. The Board considers that, while a short term permit provides greater flexibility in protecting Alberta requirements, price redetermination every two years is a better method to ensure that field prices reflect changing field value. Presumably a combination of both is most desirable. Whether the project is in the Alberta public interest on a cost benefit basis or whether the project gives the Alberta public meaningful rights to participate are also questions for consideration by the Cabinet rather than the Board.

\section{EXPORT OF GAS FROM CANADA"}

\section{Border Price}

The border price or export price is the price received by the exporter from the purchaser of gas exported at the Canada - U.S. boundary.

12 ERCB Report 74-D (February, 1974) p. 5-7.

13 Id. at 11-3.

14 For an excellent summary of National Energy Board policies and practices see Gibbs, A Review of NEB Policies and Practices and Recent Hearings, (1971) 9 Alta. L. Rev. 523. 
With respect to applications for export, s. 83 of the National Energy Board Act ${ }^{15}$ provides:

Upon an application for a licence the Board shall have regard to all considerations that appear to it to be relevant and, without limiting the generality of the foregoing, the Board shall satisfy itself that:

(a) the quantity of gas or power to be exported does not exceed the surplus remaining after due allowance has been made for the reasonably foreseeable requirements for use in Canada having regard, in the case of an application to export gas, to the trends in the discovery of gas in Canada; and

(b) the price to be charged by an applicant for gas or power exported by him is just and reasonable in relation to the public interest.

The Board has stated that consideration of the application as it relates to export price rests on three main points: ${ }^{16}$

(a) the export price must recover its appropriate share of the costs incurred;

(b) the export price should, under normal circumstances, not be less than the price to Canadians for similar deliveries in the same area;

(c) the export price of gas should not result in prices in the United States market area materially less than the least cost alternative for energy from indigenous sources.

The three tests have been categorized by the Board as follows: ${ }^{17}$ the first two tests are necessary to establish the "floor price" for exports; the third indicates the effective ceiling for competition by Canadian gas with gas from United States sources, and with other forms of energy, and at the same time indicates the target price at which an exporter of gas may reasonably aim. In satisfying itself that an export price is just and reasonable in relation to the public interest, the Board believes that such price should normally be not lower than may be necessary to enable the Canadian gas to compete effectively in the market area. The three tests will be considered in greater detail below.

(a) The export price must recover its appropriate share of the costs incurred.

The operations of certain purchasing companies are on a cost of service basis. Field price, plus transmission costs, plus rate of return on what few assets the company owns, plus operating costs, results in a price to the U.S. purchaser at the Canadian-U.S. border. On this basis there will obviously be a recovery of costs.

Where companies do not operate on this basis, evidence other than cost of service evidence must be led to prove that costs will be recovered.

(b) The export price should, under normal circumstances, not be less than the price to Canadians for similar deliveries in the same area.

Where an exporter makes sales in Canada near the point of export, the NEB has some guideline for applying this test. In a British Columbia case ${ }^{18}$ the Board stated that:

... the Board believes that it is in the public interest to propose that the border price shall at all times remain at least the equivalent in Canadian currency of 105 per cent of the comparable Canadian rate in the general area of Huntingdon, B.C. This will, in the Board's opinion, overcome in a large measure the concern for future prices, expressed

15 R.S.C. 1970 , c. N-6 as amended.

16. NEB Report (December, 1967) p. 7-1.

$17 \mathrm{Id}$. at $8-8$.

18 NEB Report (August, 1970) pp. 9-38, 9-38. 
by Inland and B.C. Hydro in their interventions, and shared to some extent by the Board. With this provision the export rate will increase if rates to Canadian consumers increase materially, and unforeseen future increases in costs will be borne in part :by export customers rather than being left wholly to be borne by Canadian customers.

Where an applicant is not making significant sales in the area, the Board may state that there is no satisfactory basis for applying the second test, or that where there are minor sales the applicant has (or has not) demonstrated, as far as it is reasonably possible to do so, that prices to Canadian customers in the same area compare favourably with the export price, or that generally the export price is (or is not) just and reasonable in the public interest.

(c) The export price of gas should not result in prices in the United States market area materially less than the least cost alternative for energy from indigenous sources.

To determine if this test is met, one takes the border price and adds to it the transmission costs from the U.S. - Canadian border to a central ceiling point or to various city gates in the U.S. market. This will result in the total gas price in the U.S. market and if that price is less than the least cost alternative for energy in that market from U.S. sources, then the third test is not met. To meet the third test the Canadian gas moving into the U.S. market must be at the competitive ceiling with the least cost U.S. energy, whether that energy is coal, No. 6 fuel oil, etc. In other words, it must be at the price beyond which it cannot rise without ceasing to be competitive with that other energy.

Applicants should be aware that a searching examination is made by the Board in determining whether tests have been met. For example, if increases occur during the term of export in transmission line throughput from the border to the U.S. market, then the laid down cost of Canadian gas may be reduced so as to result in the third test not being met at some future date. Also, the scarcity of, or price rise in, indigenous U.S. gas requires considerable analysis of alternative U.S. energy sources. U.S. - Canadian dollar exchange rates are subject to change and the effect of fluctuations, on whether the pricing tests can continue to be met, must be considered.

\section{IIA Hearing}

Regulation $11 \mathrm{~A}$ of the NEB Part VI Regulations ${ }^{19}$ states that every licence for the exportation of gas is subject to the condition that the prices to be charged for the gas are subject to review by the Board and where the Board is of the opinion that there has been a significant increase in prices for competing gas supplies or for alternative energy sources, the Board shall report its findings and recommendations to the Governor-in-Council. The Governor-in-Council may by order establish a new price for the gas. By letter dated November 26, 1973 the NEB stated it was reviewing the prices being charged by exporting companies for gas to be exported to the U.S. under existing licences. The Board asked the exporting companies to file with the Board, on or before January 22, 1974, written submissions respecting 11 matters listed in the letter. The Board also invited provincial governments, customers of exporting companies and associations, to make written submissions relevant to the listed matters. The hearing commenced on March 26, 1974 as a non-adversary hearing. Those who made submissions were given twenty minutes either before or after Board counsel and Board members cross-examined on the submission and there was no right of re-examination. No report has yet been issued by the Board but whatever report it 
does issue will be of great interest to prospective exporters and producers generally. The report will no doubt be definitive as to the third test mentioned above.

\section{3. $14(2)$ Hearing}

Section 14(2) of the National Energy Board Act states that the Board may of its own motion inquire into, hear and determine any matter or thing that, under the Act, it may inquire into, hear and determine. By notice of hearing dated May 2, 1974 the Board issued an invitation to make submissions prior to September 3, 1974 with regard to a hearing, to commence in Calgary and proceed elsewhere, sometime after the submission closing date. The purpose is to make an appraisal of the supply and deliverability of natural gas in relation to reasonably foreseeable requirements for use in Canada and for exports under existing licences. The Board will examine its method of calculating the surplus of gas remaining after due allowance has been made for the reasonably foreseeable requirements for use in Canada. The Board has indicated that the hearing will be non-adversary. When the report issues it will no doubt be definitive of Board requirements pursuant to s. 83(a) of the NEB Act. 